\title{
Copper (II) complexes of bidentate ligands exhibit potent anti-cancer activity regardless of platinum sensitivity status
}

\author{
Mohamed Wehbe ${ }^{1,2}$ (1) Cody Lo $^{1} \cdot$ Ada W. Y. Leung ${ }^{1}$ - Wieslawa H. Dragowska ${ }^{1}$. \\ Gemma M. Ryan ${ }^{1} \cdot$ Marcel B. Bally ${ }^{1,2,3,4}$
}

Received: 19 May 2017 / Accepted: 28 June 2017 / Published online: 21 July 2017

(C) The Author(s) 2017. This article is an open access publication

Summary Insensitivity to platinum, either through inherent or acquired resistance, is a major clinical problem in the treatment of many solid tumors. Here, we explored the therapeutic potential of diethyldithiocarbamate (DDC), pyrithione (Pyr), plumbagin (Plum), 8-hydroxyquinoline (8-HQ), clioquinol (CQ) copper complexes in a panel of cancer cell lines that differ in their sensitivity to platins (cisplatin/carboplatin) using a high-content imaging system. Our data suggest that the copper complexes were effective against both platinum sensitive $\left(\mathrm{IC}_{50} \sim 1 \mu \mathrm{M}\right.$ platinum) and insensitive $\left(\mathrm{IC}_{50}>5 \mu \mathrm{M}\right.$ platinum) cell lines. Furthermore, copper complexes of DDC, Pyr and 8-HQ had greater therapeutic activity compared to the copper-free ligands in all cell lines; whereas the copperdependent activities of Plum and CQ were cell-line specific. Four of the copper complexes $\left(\mathrm{Cu}(\mathrm{DDC})_{2}, \mathrm{Cu}(\mathrm{Pyr})_{2}\right.$, $\mathrm{Cu}(\mathrm{Plum})_{2}$ and $\mathrm{Cu}(8-\mathrm{HQ})_{2}$ ) showed $\mathrm{IC}_{50}$ values less than that of cisplatin in all tested cell lines. The complex copper DDC $\left(\mathrm{Cu}(\mathrm{DDC})_{2}\right)$ was selected for in vivo evaluation due to its low nano-molar range activity in vitro and the availability of an injectable liposomal formulation. Liposomal $\left(\mathrm{Cu}(\mathrm{DDC})_{2}\right)$ was tested in a fast-growing platinum-resistant A2780-CP ovarian

Mohamed Wehbe

mwehbe@bccrc.ca

1 Experimental Therapeutics, British Columbia Cancer Agency, 675 West 10th Avenue, Vancouver, BC V5Z 1L3, Canada

2 Faculty of Pharmaceutical Sciences, University of British Columbia, 2146 East Mall, Vancouver, BC V6T 1Z3, Canada

3 Department of Pathology and Laboratory Medicine, University of British Columbia, 2211 Wesbrook Mall, Vancouver, BC V6T 2B5, Canada

4 Center for Drug Research and Development, Vancouver, BC V6T 1Z4, Canada xenograft model and was found to achieve a statistically significant reduction $(50 \% ; p<0.05)$ in tumour size. This work supports the potential use of copper-based therapeutics to treat cancers that are insensitive to platinum drugs.

Keywords Cisplatin · Platinum drugs, platinum resistant cancer $\cdot$ Diethyldithiocarbamate $\cdot$ Plumbagin $\cdot$ Pyrithione . 8-hydroxyquinoline $\cdot$ Clioquinol $\cdot$ Carboplatin $\cdot$ Copper complexes $\cdot$ Copper based therapeutics

\section{Introduction}

Platinum (Pt) drugs are the most successful class of inorganic medicinal compounds used to treat cancer $[1,2]$. They are a mainstay in cancer therapy, being utilized in approximately $50 \%$ of chemotherapeutic regimens $[2,3]$. Cisplatin (CDDP) was first used to treat leukemia in the 1960s, but through several inorganic medicinal chemistry programs, other Ptbased drugs (Carboplatin (CBDCA), Oxaliplatin, Paraplatin etc.) have been produced and approved by the FDA $[2,4]$. Mechanistically, these drugs are known to act by forming PtDNA complexes that cause DNA damage that accumulate to a point that is beyond repair, ultimately leading to cell death [3, 5]. Pt drugs are currently used as first-line therapy in blood, lung, ovarian, testicular, and head and neck cancers. While some cancers are Pt sensitive and thus respond to Pt drugs [2], many others are Pt-insensitive due to inherent or acquired resistance $[3,5]$. There is a need to define drugs capable of treating Pt insensitive cancers [6].

While Pt drugs have been successful for many patients, they also produce serious side effects including nephrotoxicity, neurotoxicity and ototoxicity [7]. To address these adverse effects, many inorganic medicinal chemistry investigations have focused on developing alternatives to Pt-based drugs by replacing 
Pt with other divalent metals, such as copper [8]. Copper-based therapeutics are generally less toxic owing to the physiological processes that detoxifying excess of copper [9]. In line with this approach, many groups have demonstrated in vitro that copper complexes of natural compounds have anticancer properties; some examples include dithiocarbamates and analogues of 8hydroxyquinoline $[10,11]$. To date, however, no copper complex has transitioned into clinical use for any indication in humans. While the platins that are used in the clinic are water soluble, one major challenge of copper-based therapeutics is their inherently poor aqueous solubility [12]. This problem has made in vivo testing very challenging and required solvents containing mixtures of DMSO and Cremphor which are not clinic applicable due their high toxicity $[13,14]$. Recently, we solved the solubility issue of copper-based therapeutics by synthesising copper complexes within liposomes [12]. This technology, referred herein as Metaplex ${ }^{\mathrm{TM}}$, was used to examine the effects of copper $\mathrm{DDC}\left(\mathrm{Cu}(\mathrm{DDC})_{2}\right)$ in animals bearing a xenograft tumours [15].

In these studies, we selected five bidentate copper ligands (Scheme 1) and screened both the ligand and the corresponding copper complex in a panel of eight cancer cells. As indicated above diethyldithiocarbamate (DDC) [16, 17], Pyrithione (Pyr) [13], Plumbagin (Plum) [18, 19], 8hydroquinoline (8-HQ) [17, 20, 21] and Clioquinol (CQ) $[10,17,22,23]$ have all been shown to have anticancer activity but have never been tested directly against Pt-resistant cancers. Here we compare the activity of these complexes to the activity of CDDP and CBDCA (Scheme 2). The screen showed that many copper complexes are more active in vitro than the Pt controls. We also demonstrate that a Metaplex ${ }^{\mathrm{TM}}$ formulation of copper DDC $\left(\mathrm{Cu}(\mathrm{DDC})_{2}\right)$ was active in
(A)

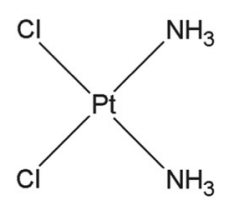

(B)

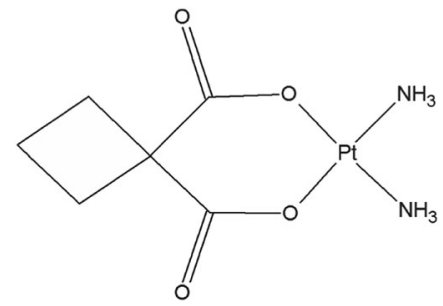

Scheme 2 Structures of commonly used platinum drugs. a Cisplatin and (b) Carboplatin

animals bearing Pt-resistant A2780-CP xenograft tumours. The results highlight the potential of the copper-based therapeutics as candidates to treat $\mathrm{Pt}$ resistant cancers.

\section{Materials and methods}

\section{Materials}

Plumbagin was obtained from Plumbago indica. Pyrithione (2-Mercaptopyridine $\mathrm{N}$-oxide sodium salt), 8 Hydroxyquinoline, Sodium Diethyldithiocarbamate trihydrate, Copper Sulfate, Clioquinol (5-Chloro-7-iodo-8quinolinol), and all other chemicals were purchased from Sigma Aldrich. Carboplatin (CBDCA) and Cisplatin (CDDP) were obtained from Hospira. 1,2-distearoyl-snglycero-3-phosphocholine (DSPC) and Cholesterol (Chol) were purchased from Avanti Polar Lipids (Alabaster, AL).

\section{Cell lines}

The A549, FaDu, Cal-27, SCC-25, and MV-4-11 cell lines were purchased from ATCC. A2780-S and A2780-CP cell

Scheme 1 Ligands and their respective copper complex structures. a DDC and $\mathrm{Cu}(\mathrm{DDC})_{2}$ (b) $\mathrm{Pyr}$ and $\mathrm{Cu}(\mathrm{Pyr})_{2}$. (c)Plum and $\mathrm{Cu}$ (Plum $)_{2}$. (d) 8-HQ and $\mathrm{Cu}(8-\mathrm{HQ})_{2}$ and (e) $\mathrm{CQ}$ and $\mathrm{Cu}(\mathrm{CQ})_{2}$

(A)

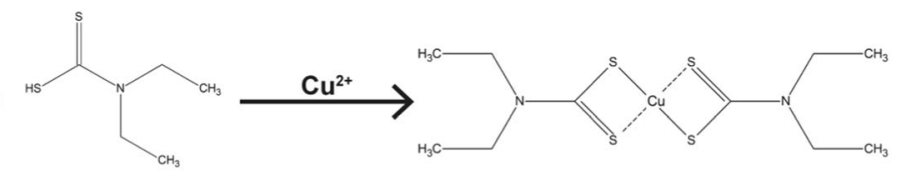

(B)

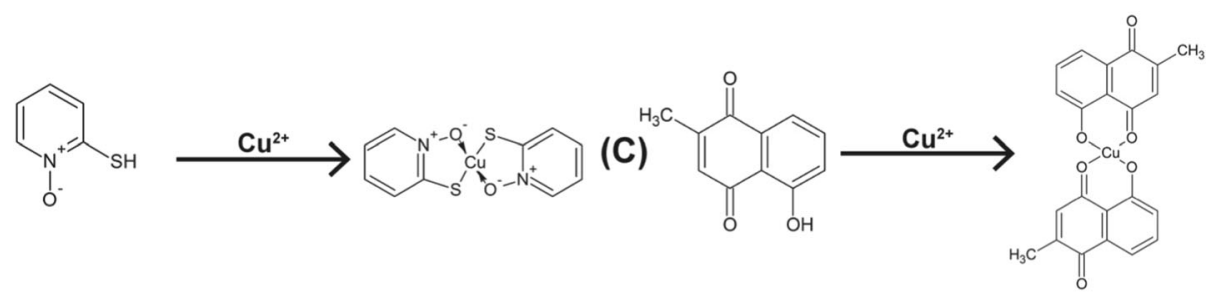

(D)<smiles>Oc1cccc2cccnc12</smiles>

(E)<smiles>Oc1c(I)cc(Cl)c2ccc3nc(c(I)cc(Cl)c12)[C@H](CC[N+]1C2=CC=Cc4c(Cl)cc(I)c(c41)O2)CC3</smiles> 
lines were obtained from Dr. Mark W. Nachtigal at the University of Manitoba (Winnipeg, Canada) and the H1933 cells were provided by Dr. William Lockwood at the BC Cancer Agency's Vancouver Research Centre (Vancouver, Canada). All cell lines were used for up to eighteen passages. A549 and H1933 cells were maintained in RPMI (Gibco). A2780-S, A2780-CP and SCC-25 were maintained in DMEM/F12 (Gibco). MV-4-11, Cal-27, and FaDu cells were maintained in IMDM (Gibco), DMEM (Gibco), and MEM (Gibco), respectively. Media for all cell lines was supplemented with $2 \mathrm{mM}$ L-glutamine (Gibco) and 10\% fetal bovine serum (Gibco) and maintained at $37{ }^{\circ} \mathrm{C}$ and $5 \% \mathrm{CO}_{2}$. Media for the SCC-25 cell line was also supplemented with $400 \mathrm{ng} /$ $\mathrm{mL}$ hydrocortisone. All cell lines tested negative for mycoplasma when obtained by the lab. Prior to drug treatment, the cells were seeded into 384 well plates and incubated $24 \mathrm{~h}$ in media prior to treatment.

\section{Cytotoxicity assay of Pt drugs, ligands and copper complexes}

For in vitro testing, copper complexes were synthesized prior to cell treatment by mixing $\mathrm{CuSO}_{4}$ and the ligand at a fixed 2:1 ratio in DMSO (50\%). The ligands DDC, CQ, 8-HQ, Plum were solubilised in DMSO and Pyr was dissolved in sterile water. CBDCA and CDDP were dissolved in sterile saline (0.9\%).

The adherent cell lines (A549, A2780-S, A2780-CP, FaDu, Cal-27, SCC-25, H1933) were exposed to the indicated compounds in triplicate wells for $72 \mathrm{~h}$. Following treatment, cells were stained in situ with Hoechst 33,342 and ethidium homodimer-I to differentiate between viable (Hoechst-positive/ethidium homodimer-negative) and dead cells that had lost membrane integrity (Hoechst-positive/ethidium-positive). Cells were imaged with the IN Cell Analyzer 2200 (GE Healthcare Life Sciences) and 4 images/well were collected. Images were analyzed with the ToolBox Developer 1.9 software (GE Healthcare Life Sciences) to obtain viable and dead cell counts based on differential staining of cell nuclei. The suspension cell line (MV-4-11) was treated for $72 \mathrm{~h}$ and viability was assessed using the Presto Blue ${ }^{\mathrm{TM}}$ assay (Life Technologies) following the manufacturer's instructions. The viability data were normalized to vehicle control $(0.5 \%$ DMSO in media) and expressed as fraction affected where value of 1 corresponded to $100 \%$ loss of cell viability relative to vehicle controls and 0 corresponds to a viability comparable to control cells in culture.

\section{$\mathrm{Cu}(\mathrm{DDC})_{2}$ liposome preparation}

For efficacy studies, copper complexes were synthesized inside liposomes, as previously described [12]. Liposomes were prepared using the extrusion method which has been well documented by others [24]. In brief, lipids were removed from freezer and desiccated for $2 \mathrm{~h}$ prior to being weighed and dissolved in chloroform at a mol:mol ratio of 55:45 (DSPC:Chol). A non-exchangeable and non-metabolizable lipid marker, ${ }^{3} \mathrm{H}$ - cholesteryl hexadecyl ether, was incorporated into the chloroform mixture and the solution was dried of chloroform using nitrogen gas and a thin film was generated using a high vacuum for $2 \mathrm{~h}$. The lipid film was rehydrated using $300 \mathrm{mM} \mathrm{CuSO}_{4}$ and extruded for at least 10 passes through a high pressure LIPEX extruder (Evonik Transferra Nanosciences, BC, Canada) using $0.1 \mu \mathrm{m}$ polycarbonate filters. The final liposome size was determined by quasi-electric light scattering with a ZetaPALS analyzer (Brookhaven). The unencapsulated copper was removed via size exclusion chromatography (SEC; Sephadex G50) and replaced with a buffer containing sucrose $(300 \mathrm{mM})$, HEPES $(20 \mathrm{mM})$ and EDTA (15 mM) (SHE buffer, $\mathrm{pH}$ 7.4). The resulting copper-free liposomes were dialyzed against a sucrose $(300 \mathrm{mM})$ and HEPES (20 mM) buffer (SH buffer, $\mathrm{pH}$ 7.4) and used for $\mathrm{Cu}(\mathrm{DDC})_{2}$ synthesis within the liposomes.

$\mathrm{Cu}(\mathrm{DDC})_{2}$ synthesis inside the liposomes was performed at $25{ }^{\circ} \mathrm{C}$ in a round bottom flask. Copper-containing liposomes $(20 \mathrm{mM})$ were mixed with DDC $(10 \mathrm{mM})$ for $1 \mathrm{~h}$. As DDC permeates across the liposomal lipid bilayer it interacts with the encapsulated copper to form $\mathrm{Cu}(\mathrm{DDC})_{2}$. The free, unreacted, DDC was removed by SEC and the $\mathrm{Cu}(\mathrm{DDC})_{2}$ containing liposomes, collected in the excluded volume were used for in vivo tumour efficacy studies.

\section{In vivo efficacy study}

A2780-CP cells that were used for subcutaneous (sc) implantation were between passages $3-10$ and maintained in DMEM/F12 (Gibco) at a confluence of 80-90\%. NRG mice (7 per group) were inoculated sc with $1 \times 10^{6}$ cells in a volume of $50 \mu \mathrm{L}$ using a 28 -gauge needle. Treatment was initiated on day four and treatment groups included the vehicle control (SH buffer), $\mathrm{CuSO}_{4}$-liposomes $(1.7 \mathrm{mg} / \mathrm{kg}$ copper, $50 \mathrm{mg} / \mathrm{kg}$ lipid), and $\mathrm{Cu}(\mathrm{DDC})_{2}$ liposomes $\left(8 \mathrm{mg} / \mathrm{kg} \mathrm{Cu}(\mathrm{DDC})_{2}\right.$ and $50 \mathrm{mg} / \mathrm{kg}$ lipid) on a Monday, Wednesday and Friday $\times 2$ weeks dosing schedule. The copper dose of the $\mathrm{CuSO}_{4}$ liposome control was equivalent to that of $\mathrm{Cu}(\mathrm{DDC})_{2}$.

Animals were monitored at least three times weekly for body weight and tumour growth which was measured with calipers and tumour volumes were calculated based on a formula of (tumour length $\mathrm{x}$ tumour width $\left.^{2}\right) / 2$. Animals were terminated by isoflorane followed by $\mathrm{CO}_{2}$ asphyxiation when animals reached a humane endpoint for these studies was defined when tumours exceeded $800 \mathrm{~mm}^{3}$ or when tumours ulcerated.

\section{Statistical analysis}

All data were plotted as mean $\pm \mathrm{SEM}$ or mean $\pm \mathrm{SD}$, as described in the figure legends. The $\mathrm{IC}_{50}$ values and $95 \%$ 
confidence intervals (CI) were extrapolated from nonlinear regression (curve fit) of the cytotoxicity curves using Prism 6.0 (GraphPad software). To determine whether the cytotoxic effects of copper complexes are associated with platinum sensitivity, the $\mathrm{IC}_{50}$ values of each copper complex was plotted against the $\mathrm{CDDP} \mathrm{IC}_{50}$ for each cell line. Each data point represents one cell line. The Pearson Correlation coefficient and corresponding two-tail $p$-values were then determined using Prism 6.0 (GraphPad software). Tumour volumes between different treatment groups were compared using one-way ANOVA followed by Tukey adjustments to correct for multiple comparisons using Prism 6.0. An adjusted $P$-value $<0.05$ was considered statistically significant.

\section{Results}

\section{Pt-resistance does not impact sensitivity of cancer cells to DDC copper complexes}

CDDP and CBDCA, two commonly used Pt-based therapeutics were tested in a pair of isogenic ovarian cancer cells: A2780-S cells are the parental cells that are sensitive to CDDP while A2780-CP cells are platinum-resistant. As shown in Fig. 1a and $\mathrm{b}$, the $\mathrm{IC}_{50}$ of CDDP and CBDCA was 3.7-and 8.5-fold greater, respectively, in the Pt resistant cells when compared to Pt sensitive cells. To determine if Pt resistance impacts activity of copper complexes, A2780-S and A2780-CP cells were treated with $\mathrm{Cu}(\mathrm{DDC})_{2}$. The data in Fig. 1c show that the $\mathrm{IC}_{50}$ value of the copper complex was not different for Pt sensitive or resistant cells. These data suggest that copper complexes may be effective regardless of $\mathrm{Pt}$ sensitivity status.

Fig. 1 Cytotoxicity profiles of $\mathrm{Pt}$ sensitive A2780-S (•) and resistant A2780-CP (ロ) ovarian cancer cells (or) following $72 \mathrm{~h}$ treatment with (a) CDDP, (b) CBDCA and (c) $\mathrm{Cu}(\mathrm{DDC})_{2}$. Fraction affected cells was assessed based on viability data normalized to vehicle controls. (d) $\mathrm{The} \mathrm{IC}_{50} \pm 95 \% \mathrm{CI}$ for A2780-S (black) and A2780-CP (white) after treatment with CDDP, CBDCA and $\mathrm{Cu}(\mathrm{DDC})_{2}$. Data is presented as the mean of 3 independent experiments \pm SEM
Activity of copper complexes in cancer cells with different Pt sensitivity

The $\mathrm{IC}_{50}$ values $\pm 95 \%$ confidence intervals for the ligands and their corresponding copper complexes are shown in Fig. 2. Cells were treated with the ligand/drug or complex $(2: 1$ ligand: $\mathrm{Cu}$ ) for $72 \mathrm{~h}$. All cell lines were also exposed to $\mathrm{CuSO}_{4}$ as a control to ensure that copper alone did not impact viability ( $\mathrm{IC}_{50}>10 \mu \mathrm{M}$ for all cell lines, data not shown). The results in Fig. 2a indicate that treatment of different cells with the ligand DDC results in an $\mathrm{IC}_{50}$ ranging from 5 to $300 \mu \mathrm{M}$ DDC. In contrast, the $\mathrm{IC}_{50}$ for the $\mathrm{Cu}(\mathrm{DDC})_{2}$ ranged from $0.02-0.15 \mu \mathrm{M}$ corresponding to differences of $90-11,000$ fold (Fig. 2a). The $\mathrm{IC}_{50}$ of Pyr ranged from 1 to $30 \mu \mathrm{M}$, and when used as a copper complex $\left(\mathrm{Cu}(\mathrm{Pyr})_{2}\right)$, the $\mathrm{IC}_{50}$ decreased to 0.1-7.4 $\mu \mathrm{M}$ (Fig. 2b). The $\mathrm{IC}_{50}$ of Plum ranged from 1.5$11 \mu \mathrm{M}$ while the $\mathrm{IC}_{50}$ of and $\mathrm{Cu}(\text { Plum })_{2}$ Ranged from 0.8 $3 \mu \mathrm{M}$ in the tested cell lines. In some cell lines (A2780-S, A2780-CP, MV-4-11, Cal-27, FaDu) there was only approximately a 2-fold difference in activity between Plum and $\mathrm{Cu}$ (Plum) $)_{2}$ (Fig. 2c). Considering the 2:1 (ligand: $\mathrm{Cu}$ ) complexation ratio, these data indicate that the copper Plum complex is as active as the uncomplexed ligand, suggesting that the cytotoxic effects observed for Plum is copper-independent. 8-HQ was more active as a copper complex $\left(\mathrm{IC}_{50}\right.$ for $\mathrm{Cu}(8-\mathrm{HQ})_{2}$ ranged between $0.2-4.5 \mu \mathrm{M}$ compared to 1.5$30 \mu \mathrm{M}$ for 8-HQ); however, in A2780-S and FaDu cells, the toxicity of 8-HQ appeared to be copper independent (Fig. 2d). The $\mathrm{IC}_{50}$ for $\mathrm{CQ}$ and $\mathrm{Cu}(\mathrm{CQ})_{2}$ ranged from 10 to $350 \mu \mathrm{M}$ and 20-60 $\mu \mathrm{M}$, respectively. Here the dependence on copper complexation for CQ cytotoxicity appears to be cell line-specific: copper-dependent activity was observed in A2780-S, A2780CP and A549 cells, whereas in MV-4-11, SCC-25 and H1933,
(A)

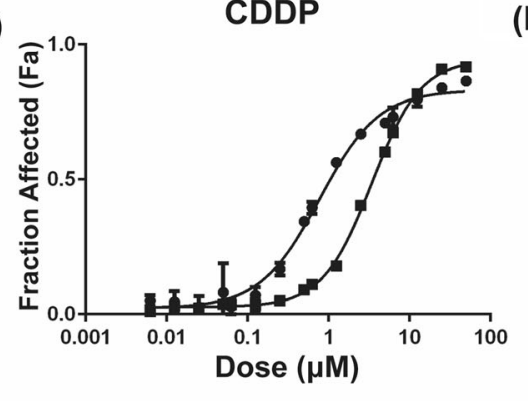

(C)

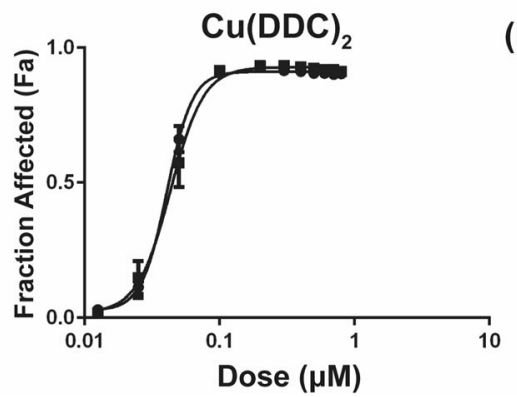

(B)

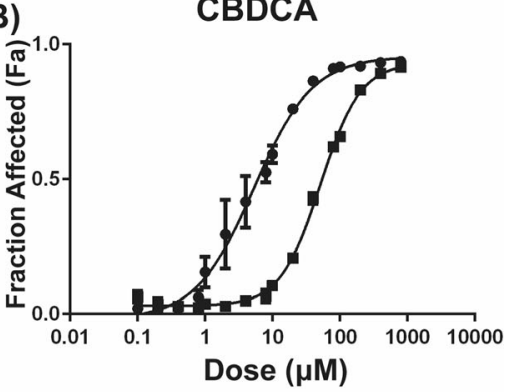

(D)

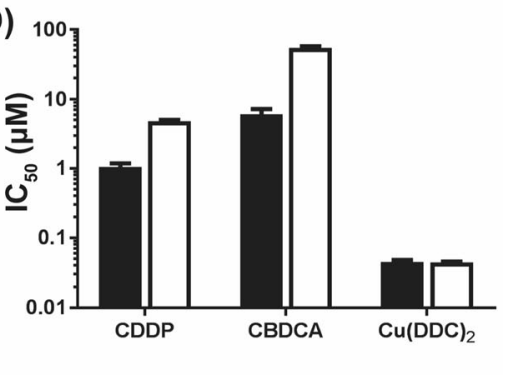




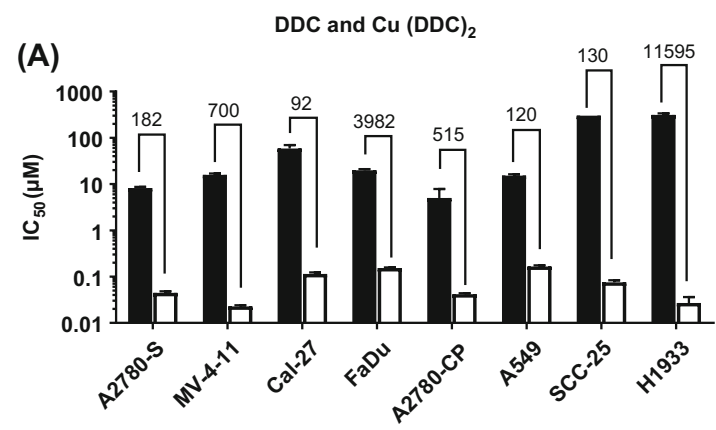

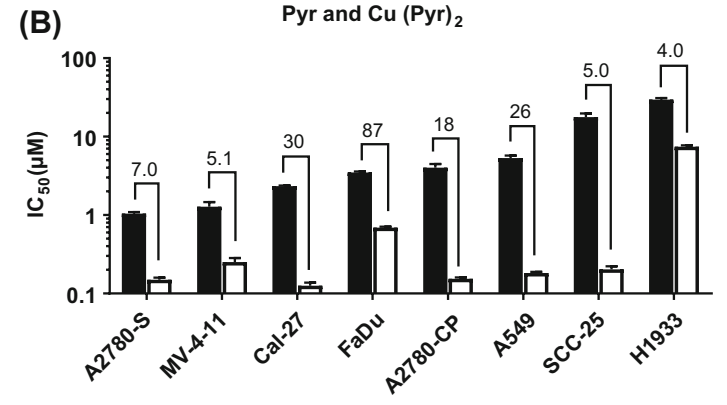

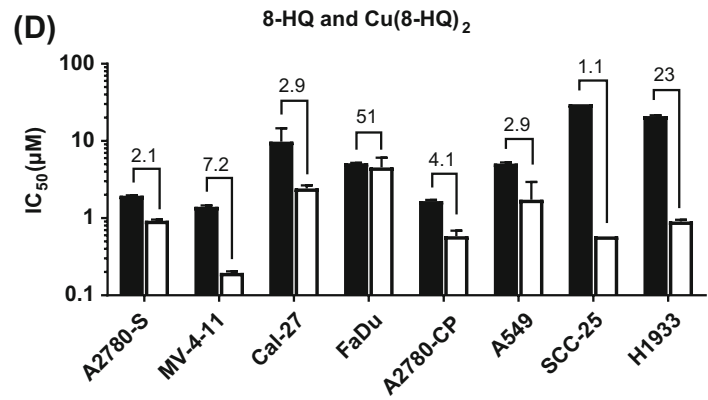

Fig. 2 Ligand/drug and copper complex cytotoxicity. A panel of 8 cancer cell lines (A2780-S, MV-4-11, A549, SCC-25, Cal-27, A2780-CP, FaDu and $\mathrm{H} 1933)$ were treated for $72 \mathrm{~h}$ with the ligand/drug (ם) or copper complex (口): (a) $\mathrm{DDC} / \mathrm{Cu}(\mathrm{DDC})_{2}$, (b) $\mathrm{Pyr} / \mathrm{Cu}(\mathrm{Pyr})_{2}$, , (c) Plum $/ \mathrm{Cu}(\mathrm{Plum})_{2}$, (d) $8-\mathrm{HQ} / \mathrm{Cu}(8-\mathrm{HQ})_{2}$ and (e) $\mathrm{CQ} / \mathrm{Cu}(\mathrm{CQ})_{2}$. The

the cytotoxicity of CQ was copper-independent. Moreover, $\mathrm{CQ}$ appears to be more cytotoxic than $\mathrm{Cu}(\mathrm{CQ})_{2}$ in Cal-27 and $\mathrm{FaDu}$ cells (Fig. 2e).

The $\mathrm{IC}_{50} \mathrm{~s}$ obtained from cytotoxicity assays for each cell line were arranged as a heat-map in order of Pt sensitivity to CDDP (Fig. 3). An $\mathrm{IC}_{50}$ cut-off of $10 \mu \mathrm{M}$ was used to distinguish more potent agents from those that were regarded as pharmaceutically inactive. In general, the ligands appear to be less active in the Pt resistant cell lines whereas the copper complexes augmented anti-cancer activity considerably. The Pyr, Plum and 8-HQ ligands showed activity in most cell lines, however, their activity was enhanced in the tested cell lines when used as complexes with copper; where the greatest increases were observed for $\mathrm{Cu}(\mathrm{Pyr})_{2}$. DDC and $\mathrm{CQ}$ were the least active ligands. The $\mathrm{Cu}(\mathrm{CQ})_{2}$ complex did not show improvement in cytotoxicity whereas the copper complex of DDC was the most active in all cell lines. In general, except for $\mathrm{Cu}(\mathrm{Pyr})_{2}$, the activity of the copper complexes used in our
(C) Plum and $\mathrm{Cu}(\text { Plum })_{2}$

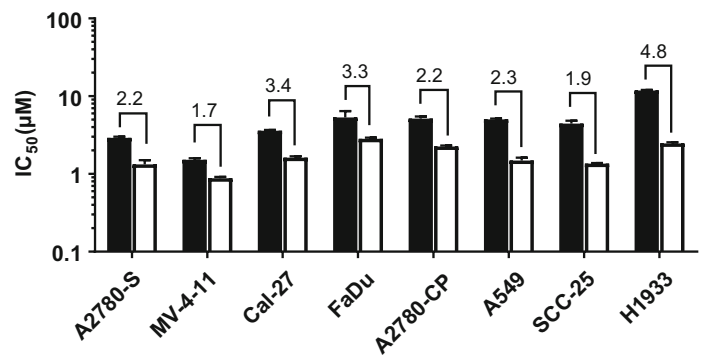

(E)

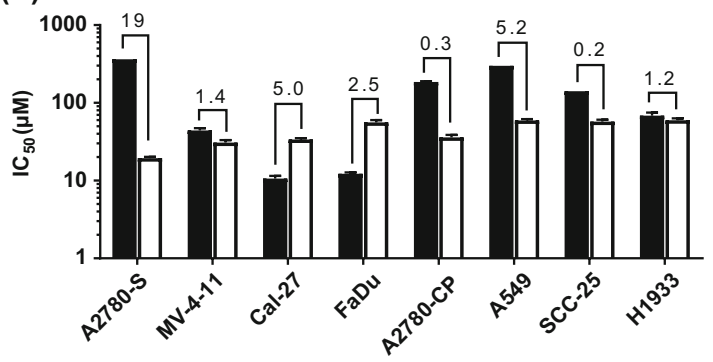

$\mathrm{IC}_{50}$ values were obtained based on the viability data acquired with IN Cell 2200 or PrestoBlue ${ }^{\circledR}(\mathrm{M}-\mathrm{V}-411)$. The fold difference between the $\mathrm{IC}_{50}$ of the ligand and respective copper complex is shown above the histogram bars

study show no correlation with Pt CDDP sensitivity in tested cell lines (Table 1). The heatmap indicates that $\left(\mathrm{Cu}(\mathrm{DDC})_{2}\right.$ is the most effective complex tested against Pt-resistant cancers.

\section{Efficacy of liposomal cu(DDC $)_{2}$ in a Pt-resistant A2780-CP tumour xenograft model}

$\mathrm{Cu}(\mathrm{DDC})_{2}$ has represented a formulation challenge because of its poor aqueous solubility. Previously we developed a strategy where the $\mathrm{Cu}(\mathrm{DDC})_{2}$ was synthesized inside a liposomal formulation [12]. Here we used this formulation (see Methods) to assess the activity of the $\mathrm{Cu}(\mathrm{DDC})_{2}$ in a Ptresistant A2780-CP subcutaneous tumour xenograft model. The data, shown in Fig. 4, indicate that $\mathrm{Cu}(\mathrm{DDC})_{2}$ engendered a statistically $(p<0.05)$ significant $\sim 50 \%$ reduction in tumour burden when compared to the activity of the vehicle control. These data provide proof-of-concept results suggesting that liposomal copper complexes have the potential to be 
Fig. 3 Screen of copper based therapeutics in cancer cells with different Pt sensitivities. $\mathrm{IC}_{50}$ values for Pt drugs (CDDP and CBDCA), ligands (DDC, Pyr, Plum, 8-HQ, CQ) and respective copper complexes are shown for cancer cell lines of differing origin arranged in order of sensitivity to $\mathrm{CDDP}$. $\mathrm{IC}_{50}$ values were calculated from viability data ( $n=3$ experiments/each cell line) obtained with IN Cell Analyzer 2200 platform or PrestoBlue $^{\mathrm{TM}}$ assay (MV-4-11 cells). The agents with $\mathrm{IC}_{50}$ values $>10 \mathrm{uM}$ (black) are considered inactive

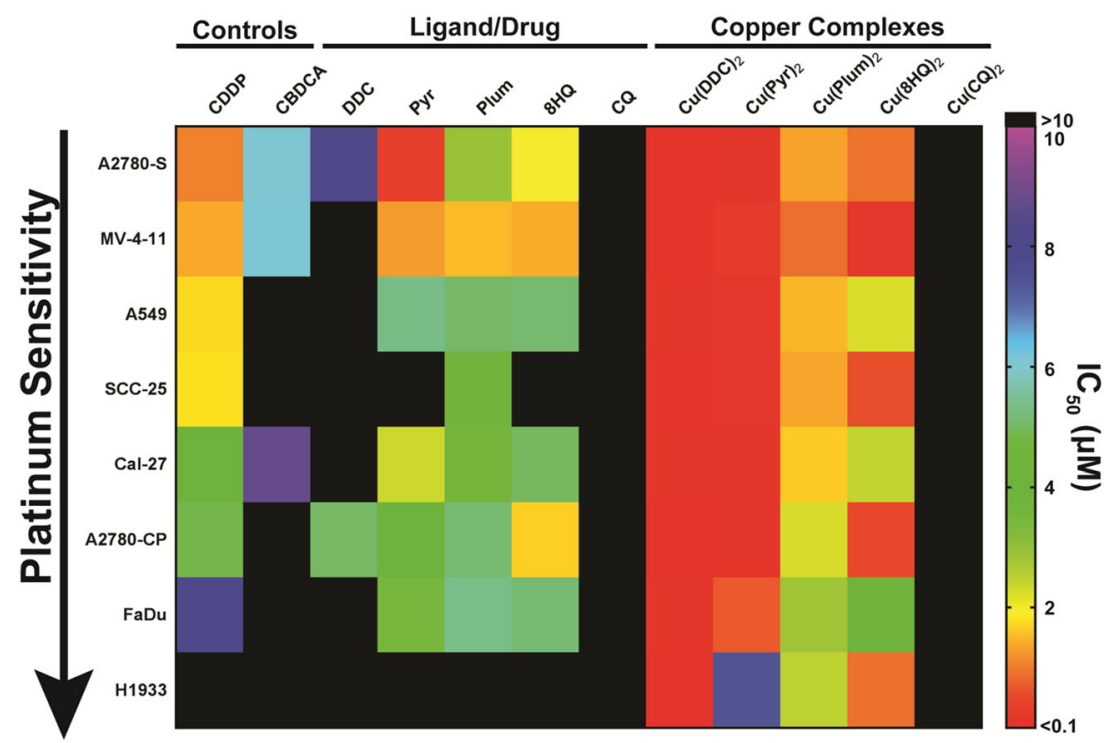

developed as a novel class of therapeutic agents for use in the treatment of Pt-resistant cancers.

\section{Discussion}

Pt drugs are standard first-line therapies for the treatment of lung, ovarian, and head and neck cancers [25, 26]. While some cancers are inherently resistant, the widespread use of Pt-based therapies has resulted in the development of resistant cancers, often in the relapse setting where prognosis is poor $[6$, 25]. In vitro, cell lines can be developed to replicate this effect (e.g. A2780-CP), wherein cells are treated with low dose Pt drugs such as CDDP over extended periods of time until resistance is observed through changes in $\mathrm{IC}_{50}$ values [27, 28]. The two major mechanisms responsible for Pt resistance are DNA repair and Pt drug transport into cancer cells [2, 29]. Through extensive characterization, it was determined that at equivalent levels of drug accumulation, the A2780-CP cell line is 2-fold more efficient at repairing Cisplatin-DNA lesions when compared to the parental, Pt-sensitive cell line (A2780-S) [29]. The copper transporter CTR1 is the major influx transporter for cisplatin both in vitro and in vivo and has been reported to be reduced in cisplatin resistant cancers $[25,30]$. This mechanism was attributed to cisplatin influx resulting in the rapid degradation of CTR1 [31]. Identifying

Table 1 Correlation between CDDP and copper complex sensitivity based on the $\mathrm{IC}_{50}$ values

\begin{tabular}{llllll}
\hline Drug & $\mathrm{Cu}(\mathrm{DDC})_{2}$ & $\mathrm{Cu}(\mathrm{Pyr})_{2}$ & $\mathrm{Cu}(\mathrm{Plum})_{2}$ & $\mathrm{Cu}(8-\mathrm{HQ})_{2}$ & $\mathrm{Cu}(\mathrm{CQ})_{2}$ \\
\hline Pearson $\mathrm{R}^{2}$ & 0.0680 & 0.6966 & 0.1030 & 0.0880 & 0.4365 \\
$P$-value & 0.0 .5325 & 0.0100 & 0.4382 & 0.4755 & 0.0745 \\
Significant & No & Yes & No & No & No \\
\hline
\end{tabular}

new therapeutic entities that are active in Pt resistant cancers is a priority to improve treatment outcome for patients.

The ovarian cancer cell line A2780-CP had a clear resistance to CDDP and CBDCA when compared to the activity of these drugs in A2780-S cells. In order to test the utility of copper based therapies in platinum-resistant cancer cells, preliminary studies investigated $\mathrm{Cu}(\mathrm{DDC})_{2}$ in $\mathrm{Pt}$ sensitive and insensitive cell lines. $\mathrm{Cu}(\mathrm{DDC})_{2}$ was active irrespective of $\mathrm{Pt}$ sensitivity at equivalent doses. This $\mathrm{Pt}$ sensitivity-independent activity could be explained by the $\mathrm{Cu}(\mathrm{DDC})_{2}$ mechanism of toxicity which overcomes resistance mechanisms commonly seen in Pt-resistant cancers. $\mathrm{Cu}(\mathrm{DDC})_{2}$ is able to accumulate in cancer cells irrespective of CTR1 expression [32] and

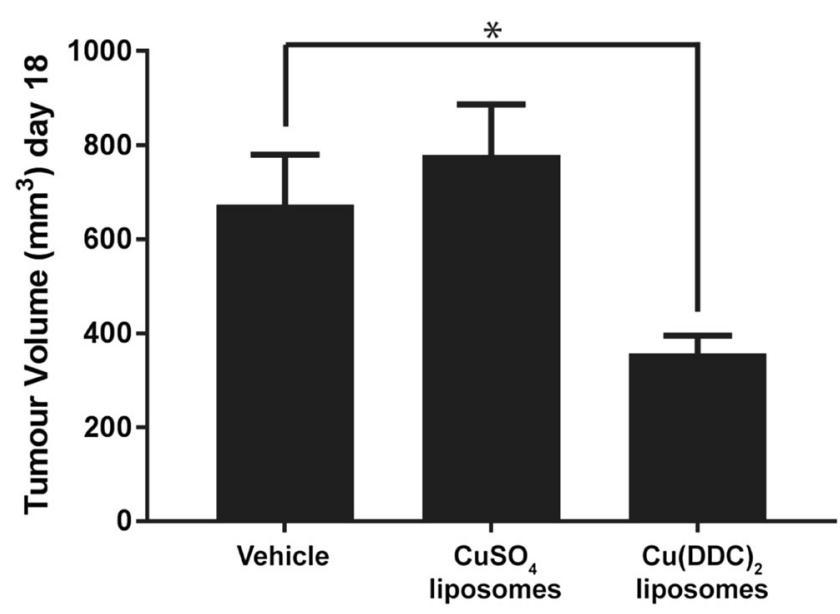

Fig. 4 In vivo activity of liposomal $\mathrm{Cu}(\mathrm{DDC})_{2}$ in animals bearing $\mathrm{Pt}$ resistant A2780-CP tumours. $1 \times 10^{6}$ A2780-CP cells were inoculated sc into immune-compromised NRG mice which were subsequently treated intravenously with vehicle ( $\mathrm{SH}$ buffer), $\mathrm{CuSO}_{4}$-liposomes $(1.7 \mathrm{mg} / \mathrm{kg}$ copper, $50 \mathrm{mg} / \mathrm{kg}$ lipid), and $\mathrm{Cu}(\mathrm{DDC})_{2}$ liposomes $\left(8 \mathrm{mg} / \mathrm{kg} \mathrm{Cu}(\mathrm{DDC})_{2}\right.$ and $50 \mathrm{mg} / \mathrm{kg}$ lipid) using a $3 \mathrm{x}$ per week for 2 weeks dosing schedule. Mean tumour volume was determined on day 18 (the humane endpoint for vehicle treated animals). Data represents the mean $\pm \operatorname{SEM}(n=7)$. * indicates statistical difference $(p<0.05)$ 
cytotoxicity is mediated through proteosome inhibition [16]. These results suggest that CBTs use mechanisms of cytotoxicity outside of those used by platinums and warrant further investigations in resistant cancers.

Five copper binding ligands (DDC, Pyr, Plum, 8-HQ and CQ) were tested in a panel of eight cancer cell lines of different origins (blood, lung, ovarian, head and neck) and differing sensitivity to Pt-based drugs exemplified by CDDP/CBDCA activity. Our in vitro data suggest that the cytotoxicity of ligands DDC, Pyr and 8-HQ appeared to be copper-dependent whereas the cytotoxicity of Plum and CQ were copper independent. This finding is important as both DSF (metabolized to $\mathrm{DDC}$ in vivo) + $\mathrm{Cu}$-Gluconate and $\mathrm{CQ}$ were involved in clinical trials with no listed benefit [33-35]. By knowing the relationship between $\mathrm{Cu}$ and the activity of the complex, it can be reasoned that ligands such as DDC, Pyr and 8-HQ should be administered as copper complexes to ensure that the active (copper complexed) species reaches the cancer cells. This is supported by work performed by Katano et al. which showed that Pt resistant cancers have lower basal levels of copper, suggesting that the uncomplexed ligands would be less active [30]. In the current study, H1933 was the least sensitive to Pt as reflected by a $>10 \mu \mathrm{M} \mathrm{IC}_{50}$ cytotoxicity to all the ligands tested. In contrast, Plum and CQ could be used as single agents and pharmaceutical challenges associated with their solubility may be overcome using the Metaplex ${ }^{\mathrm{TM}}$ approach that we have described previously to prepare a nanomedicine formulation of $\mathrm{Cu}(\mathrm{DDC})_{2}$ with no loss in activity $[12,15]$. $\mathrm{Cu}$ (II) dominates the coordination chemistry of copper and was the focus of this work but $\mathrm{Cu}(\mathrm{I})$ complexes with therapeutic activity do exist [9]. For example, Han et al. tested the $\mathrm{Cu}$ (I)-DDC complex in a subcutaneous tumour model of adenocarcinoma with $\sim 60 \%$ reduction in tumour burden by day 25 [36]. This research focused on $\mathrm{Cu}$ (II) species for two reasons. First, $\mathrm{Cu}(\mathrm{I})$ is not stable in aqueous solutions and undergoes conversion to $\mathrm{Cu}$ (II) [37]. The creation of the $\mathrm{Cu}(\mathrm{I})$ complexes in aqueous solutions would require characterization to ensure that the $\mathrm{Cu}(\mathrm{I})$ and not the $\mathrm{Cu}(\mathrm{II})$ complexes was being synthesized. Second, $\mathrm{Cu}(\mathrm{I})$ and $\mathrm{Cu}(\mathrm{II})$ preferentially coordinate with different atoms. $\mathrm{Cu}$ (II) is able to complex "hard" donors such as nitrogen and oxygen, whereas $\mathrm{Cu}(\mathrm{I})$ is known to coordinate with thiols and thioesters [38].

Our data support the utility of copper-based therapeutics in the treatment of Pt-insensitive cancer. To date, not a single copper-based therapeutic has received FDA approval. This is in part due to the solubility challenges associated with these complexes. All copper complexes studied as well as the ligands Plum, 8-HQ and CQ are water insoluble $(<0.1 \mathrm{mg} / \mathrm{mL})$; in contrast, DDC and Pyr are water soluble as ligands but their therapeutic activity is significantly enhanced in the presence of $\mathrm{Cu}$. All copper complexes had to be dissolved in DMSO (final concentration $0.5 \%$ ) to allow for in vitro testing. The ICH guidelines for residual solvents in a product indicate that
DMSO cannot be included at concentrations above $0.5 \%$ which would be needed to administer the complexes at relevant doses [39]. While the ligands used in this work are approved agents, the copper complexes themselves have never been administered as therapeutic agents. Thus, in vivo testing of selected copper complexes should be done in conjunction with cytotoxicity studies in healthy human cells. This was previously done for $\mathrm{Cu}(\mathrm{DDC})_{2}$ and both ligand as well as the copper complex exhibited $\mathrm{IC}_{50}$ values greater than $10 \mu \mathrm{M}$ when added to primary (normal) human bronchial epithelial cells [12].

We have previously disclosed the Metaplex ${ }^{\mathrm{TM}}$ technology as a platform approach to formulate copper complexes inside liposomes in order to overcome solubility issues and to allow for parenteral administration of copper complexed ligands [12]. Thus, as a proof-of-concept we tested a liposomal formulation of $\mathrm{Cu}(\mathrm{DDC})_{2}$ in a xenograft tumour model of A2780-CP Ptresistant ovarian cancer. In this study, we showed that liposomal $\mathrm{Cu}(\mathrm{DDC})_{2}(8 \mathrm{mg} / \mathrm{kg})$ but not $\mathrm{Cu}$-liposomes produced a statistically significant $\sim 50 \%$ reduction in tumour burden when compared to the vehicle control. This difference is not considered clinically relevant (based on RECIST criteria [40]) but the results does suggest that copper complexes are a class of therapeutic that should be further investigated. $\mathrm{Cu}(\mathrm{DDC})_{2}$ pharmacokinetics for the liposomal product show rapid release from the liposome and degradation in the plasma, and as such would require further development to improve circulation lifetime and stability [12]. Also the use of this formulated $\mathrm{Cu}(\mathrm{DDC})_{2}$ preparation in combination with other agents typically combined with platinums (eg. the taxanes [41]) is warranted. The other complexes discussed are proposed as future developments to identify those which have activity as single agents in Pt resistant cancers and as those which can augment therapy in combination with traditional chemotherapeutics.

\section{Conclusion}

Pt drugs have been widely successful in the treatment of cancer. The treatment of Pt-resistant cancers has been a pharmaceutical focus that requires new therapeutics with mechanisms of action differing from those invoked by Pt-based therapies. Copper-based therapeutics represents a new class of drugs that can address many of the challenges associated with Ptresistant cancers. Our data show that four out of five screened ligands that form copper complexes reached $\mathrm{IC}_{50}$ values below $10 \mu \mathrm{M}$ in the eight cancer cell lines regardless of their $\mathrm{Pt}$ sensitivity. Additionally, we tested one of these complexes $\left(\mathrm{Cu}(\mathrm{DDC})_{2}\right)$ in vivo in a Pt-resistant ovarian cancer xenograft model and attained a 50\% reduction in tumor volume when compared to vehicle-treated control mice. These data not only provide in vivo validation that copper-based therapeutics could be used to treat Pt-resistant cancer but also provides proof-of-concept that the Metaplex ${ }^{\mathrm{TM}}$ technology could be 
used to develop formulations of inherently insoluble copper complexes for pre-clinical and clinical evaluations.

Acknowledgements The authors would like to acknowledge N. Dos Santos and the staff of the Investigational Drug Program at the BC Cancer Agency for their contributions to the toxicity, pharmacokinetic and efficacy studies.

\section{Compliance with ethical standards}

Conflict of interest All authors declare no conflict of interests.

Funding The research described in this original paper was supported by grant funding from the Canadian Cancer Society Research Institute (Award \# 702491 and 705,290). Additional funding was obtained from the BC Cancer Foundation and the Centre for Drug Research and Development.

Ethical approval Studies involving the use of animals were completed under an Animal Care Protocol approved by the University of British Columbia's Animal Care Committee. Health assessment was completed using a standard operating procedure (SOP), approved by the Institutional Animal Care Committee.

Open Access This article is distributed under the terms of the Creative Commons Attribution 4.0 International License (http:// creativecommons.org/licenses/by/4.0/), which permits unrestricted use, distribution, and reproduction in any medium, provided you give appropriate credit to the original author(s) and the source, provide a link to the Creative Commons license, and indicate if changes were made.

\section{References}

1. Desoize B (2004) Metals and metal compounds in cancer treatment. Anticancer Res 24(3A):1529-1544

2. Kelland L (2007) The resurgence of platinum-based cancer chemotherapy. Nat Rev Cancer 7(8):573-584. doi:10.1038/nrc2167

3. Johnstone TC, Park GY, Lippard SJ (2014) Understanding and improving platinum anticancer drugs-phenanthriplatin. Anticancer Res 34(1):471-476

4. Rosenberg B, VanCamp L, Trosko JE, Mansour VH (1969) Platinum compounds: a new class of potent antitumour agents. Nature 222(5191):385-386

5. Wang D, Lippard SJ (2005) Cellular processing of platinum anticancer drugs. Nat Rev Drug Discov 4(4):307-320. doi:10.1038/nrd1691

6. Mantia-Smaldone GM, Edwards RP, Vlad AM (2011) Targeted treatment of recurrent platinum-resistant ovarian cancer: current and emerging therapies. Cancer Manag Res 3:25-38. doi:10. 2147/CMR.S8759

7. Rybak LP, Mukherjea D, Jajoo S, Ramkumar V (2009) Cisplatin ototoxicity and protection: clinical and experimental studies. Tohoku J Exp Med 219(3):177-186

8. Marzano C, Pellei M, Tisato F, Santini C (2009) Copper complexes as anticancer agents. Anti Cancer Agents Med Chem 9(2):185-211

9. Santini C, Pellei M, Gandin V, Porchia M, Tisato F, Marzano C (2014) Advances in copper complexes as anticancer agents. Chem Rev 114(1):815-862. doi:10.1021/cr400135x

10. Daniel KG, Chen D, Orlu S, Cui QC, Miller FR, Dou QP (2005) Clioquinol and pyrrolidine dithiocarbamate complex with copper to form proteasome inhibitors and apoptosis inducers in human breast cancer cells. Breast Cancer Research : BCR 7(6):R897-R908. doi: $10.1186 /$ bcr1322

11. Jiang H, Taggart JE, Zhang X, Benbrook DM, Lind SE, Ding W-Q (2011) Nitroxoline (5-amino-8-hydroxyquinoline) is more a potent anti-cancer agent than clioquinol (5-chloro-7-iodo-8-quinoline). Cancer Lett 312(1):11-17. doi:10.1016/j.canlet.2011.06.032

12. Wehbe M, Anantha M, Backstrom I, Leung A, Chen K, Malhotra A, Edwards K, Bally MB (2016) Nanoscale reaction vessels designed for synthesis of copper-drug complexes suitable for preclinical development. PLoS One 11(4):e0153416. doi:10.1371/journal. pone. 0153416

13. Liu NN, Liu CJ, Li XF, Liao SY, Song WB, Yang CS, Zhao C, Huang HB, Guan LX, Zhang PQ, Liu ST, Hua XL, Chen X, Zhou P, Lan XY, Yi SG, Wang SQ, Wang XJ, Dou QP, Liu JB (2014) A novel proteasome inhibitor suppresses tumor growth via targeting both $19 \mathrm{~S}$ proteasome deubiquitinases and $20 \mathrm{~S}$ proteolytic peptidases. Sci Rep 4:5240. doi:10.1038/Srep05240

14. Barrea RA, Chen D, Irving TC, Dou QP (2009) Synchrotron X-ray imaging reveals a correlation of tumor copper speciation with Clioquinol's anticancer activity. J Cell Biochem 108(1):96-105. doi:10.1002/jcb.22231

15. Wehbe M, Anantha M, Shi M, Leung A, Dragowska WH, Sanche L, Bally MB (2017) Development and optimization of an injectable formulation of copper diethyldithiocarbamate, an active anticancer agent. International journal of nanomedicine:in press

16. Cvek B, Milacic V, Taraba J, Dou QP (2008) Ni(II), cu(II), and $\mathrm{Zn}$ (II) Diethyldithiocarbamate complexes show various activities against the proteasome in breast cancer cells. J Med Chem 51(20):6256-6258. doi:10.1021/jm8007807

17. Wang F, Jiao P, Qi M, Frezza M, Dou QP, Yan B (2010) Turning tumor-promoting copper into an anti-cancer weapon via highthroughput chemistry. Curr Med Chem 17(25):2685-2698

18. Nazeem S, Azmi AS, Hanif S, Ahmad A, Mohammad RM, Hadi SM, Kumar KS (2009) Plumbagin induces cell death through a copper-redox cycle mechanism in human cancer cells. Mutagenesis 24(5):413-418. doi:10.1093/mutage/gep023

19. Chen ZF, Tan MX, Liu LM, Liu YC, Wang HS, Yang B, Peng Y, Liu HG, Liang H, Orvig C (2009) Cytotoxicity of the traditional chinese medicine (TCM) plumbagin in its copper chemistry. Dalton Trans 48:10824-10833. doi:10.1039/b910133k

20. Tardito S, Barilli A, Bassanetti I, Tegoni M, Bussolati O, FranchiGazzola R, Mucchino C, Marchio L (2012) Copper-dependent cytotoxicity of 8-Hydroxyquinoline derivatives correlates with their hydrophobicity and does not require Caspase activation. J Med Chem 55(23):10448-10459. doi:10.1021/jm301053a

21. Zhai SM, Yang L, Cui QC, Sun Y, Dou QP, Yan B (2010) Tumor cellular proteasome inhibition and growth suppression by 8 hydroxyquinoline and clioquinol requires their capabilities to bind copper and transport copper into cells. J Biol Inorg Chem 15(2): 259-269. doi:10.1007/s00775-009-0594-5

22. Ding WQ, Liu BL, Vaught JL, Yamauchi H, Lind SE (2005) Anticancer activity of the antibiotic clioquinol. Cancer Res 65(8): 3389-3395

23. Schimmer AD (2011) Clioquinol - a novel copper-dependent and independent proteasome inhibitor. Curr Cancer Drug Targets 11(3): 325-331

24. Hope MJ, Bally MB, Webb G, Cullis PR (1985) Production of large Unilamellar vesicles by a rapid extrusion procedure - characterization of size distribution, trapped volume and ability to maintain a membrane-potential. Biochim Biophys Acta 812(1):55-65. doi:10. 1016/0005-2736(85)90521-8

25. Shen D-W, Pouliot LM, Hall MD, Gottesman MM (2012) Cisplatin resistance: a cellular self-defense mechanism resulting from multiple epigenetic and genetic changes. Pharmacol Rev 64(3):706-721. doi:10.1124/pr.111.005637 
26. McWhinney SR, Goldberg RM, McLeod HL (2009) Platinum neurotoxicity Pharmacogenetics. Mol Cancer Ther 8(1):10-16. doi:10. 1158/1535-7163.MCT-08-0840

27. Engelke LH, Hamacher A, Proksch P, Kassack MU (2016) Ellagic acid and resveratrol prevent the development of Cisplatin resistance in the epithelial ovarian cancer cell line A2780. J Cancer 7(4):353363. doi: $10.7150 /$ jca. 13754

28. Nikounezhad N, Nakhjavani M, Shirazi FH (2016) Generation of Cisplatin-resistant ovarian cancer cell lines. Iranian J Pharm Sci 12(1):11-20

29. Parker RJ, Eastman A, Bostickbruton F, Reed E (1991) Acquired Cisplatin resistance in human ovarian-cancer cells is associated with enhanced repair of Cisplatin-DNA lesions and reduced drug accumulation. J Clin Invest 87(3):772-777. doi:10.1172/Jci115080

30. Katano K, Kondo A, Safaei R, Holzer A, Samimi G, Mishima M, Kuo YM, Rochdi M, Howell SB (2002) Acquisition of resistance to cisplatin is accompanied by changes in the cellular pharmacology of copper. Cancer Res 62(22):6559-6565

31. Jandial DD, Farshchi-Heydari S, Larson CA, Elliott GI, Wrasidlo WJ, Howell SB (2009) Enhanced delivery of cisplatin to intraperitoneal ovarian carcinomas mediated by the effects of bortezomib on the human copper transporter 1. Clin Cancer Res 15(2):553560. doi:10.1158/1078-0432.CCR-08-2081

32. Fujie T, Murakami M, Yoshida E, Tachinami T, Shinkai Y, Fujiwara Y, Yamamoto C, Kumagai Y, Naka H, Kaji T (2016) Copper diethyldithiocarbamate as an activator of $\mathrm{Nrf} 2$ in cultured vascular endothelial cells. J Biol Inorg Chem 21(2):263-273. doi:10.1007/ s00775-016-1337-z

33. Utah Uo (2008) Phase I study of disulfiram and copper gluconate for the treatment of refractory solid tumors involving the liver https://ClinicalTrials.gov/show/NCT00742911

34. Ritchie CW, Bush AI, Mackinnon A, Macfarlane S, Mastwyk M, MacGregor L, Kiers L, Cherny R, Li QX, Tammer A, Carrington
D, Mavros C, Volitakis I, Xilinas M, Ames D, Davis S, Beyreuther K, Tanzi RE, Masters CL (2003) Metal-protein attenuation with iodochlorhydroxyquin (clioquinol) targeting Abeta amyloid deposition and toxicity in Alzheimer disease: a pilot phase 2 clinical trial. Arch Neurol 60(12):1685-1691. doi:10.1001/archneur.60.12.1685

35. Dale SW, Fishbein L (1970) Stability of sodium diethyldithiocarbamate in aqueous solution by proton magnetic resonance spectroscopy. J Agric Food Chem 18(4):713-719

36. Han JB, Liu LM, Yue XQ, Chang JJ, Shi WD, Hua YQ (2013) A binuclear complex constituted by diethyldithiocarbamate and copper(I) functions as a proteasome activity inhibitor in pancreatic cancer cultures and xenografts. Toxicol Appl Pharm 273(3):477483. doi:10.1016/j.taap.2013.09.009

37. Rizvi MA, Akhoon SA, Maqsood SR, Peerzada GM (2015) Synergistic effect of perchlorate ions and acetonitrile medium explored for extension in copper redoximetry. J Anal Chem 70(5):633-638. doi:10.1134/S1061934815050093

38. Haas KL, Franz KJ (2009) Application of metal coordination chemistry to explore and manipulate cell biology. Chem Rev 109(10): 4921-4960. doi:10.1021/cr900134a

39. ICH (1997) Q3C Impurities: residual solvents international conference on harmonisation of technical requirements for registration of pharmaceuticals for human use (ICH)

40. Eisenhauer EA, Therasse P, Bogaerts J, Schwartz LH, Sargent D, Ford R, Dancey J, Arbuck S, Gwyther S, Mooney M, Rubinstein L, Shankar L, Dodd L, Kaplan R, Lacombe D, Verweij J (2009) New response evaluation criteria in solid tumours: revised RECIST guideline (version 1.1). Eur J Cancer 45(2):228-247. doi:10.1016/j.ejca.2008.10.026

41. Crown J, Pegram M (2003) Platinum-taxane combinations in metastatic breast cancer: an evolving role in the era of molecularly targeted therapy. Breast Cancer Res Treat 79(Suppl 1):S11-S18 